\title{
STOMATOLOGY
}

UDC $614.23 ; 616.31 ; 617.52-089$

\section{To the question of the history of the formation and development of orthopedic dental care in Russia}

\author{
E. N. Antonova, I. M. Akulin, T. V.Davydova \\ St. Petersburg State University, \\ 7-9, Universitetskaya nab., St. Petersburg, 199034, Russian Federation
}

For citation: Antonova E. N., Akulin I.M., Davydova T.V. To the question of the history of the formation and development of orthopedic dental care in Russia. Vestnik of Saint Petersburg University. Medicine, 2021, vol. 16, issue 1, pp. 50-55. https://doi.org/10.21638/spbu11.2021.106

\begin{abstract}
The article is devoted to the formation and development of orthopedic dental care in Russia. The focus is on the analysis of the organizational aspects of the provision of orthopedic care in general, the study of the processes of the emergence and formation of medical and social programs in terms of the provision of orthopedic dental care. The beginning of the article is connected with the background and history of the development of orthopedic dental care in Russia. The emergence of the term "medical and social care" in general and in dentistry in particular refers to the Soviet post-revolutionary period of national history. The authors analyze aspects of the history of the formation and development of medical and social programs for certain segments of the population, consider the quality and accessibility of orthopedic dental care created in the Soviet health care system, the specifics of development and legal regulation of the industry in the Soviet period. According to the authors, in the entire history of domestic health care, mass free and generally accessible provision of complex and currently quite expensive dental orthopedic care was implemented for the first time in the world in the Soviet Union for the insured population of the country. However, the level of training of specialists, the quality of materials, tools and manufactured prostheses remained low. The population of the country did not impose high aesthetic and functional requirements for the dentures and it also contributed to their low quality.
\end{abstract}

Keywords: dentistry, dental prosthetics, prosthetic dentistry, prosthetics care, medical and social assistance.

The emergence of professional dental care in Russia dates back to the period of Muscovy, the epoch of the reign of Ivan IV, when pharmacists and barbers were invited from England to serve the court of the Russian Tsar [1]. As to the emergence of the state or-

(C) St. Petersburg State University, 2021 
ganization of medicine, it is associated with the foundation of the Pharmaceutical Order in 1620. However, this reform remained unnoticed for the main population of the state, since the innovation did not extend beyond the privileged circles. In the Russian Empire until the $19^{\text {th }}$ century, the majority of the population was deprived of dental care. The wellto-do segments of the population of the capital and large cities received help from private practitioners (mostly foreigners), the poor used the services of barbers who did not have medical education, and there was almost no dental care in rural areas [2].

The government did not allocate funds for public health and allowed the opening of private dental schools and clinics. Therefore, denture care in the second half of the $19^{\text {th }}$ century was provided to the population by free-practice doctors in private dental offices and clinics. Dental prosthetics was quite expensive and very few city dwellers could afford it, whereas this kind of help was practically absent in the countryside. Dental care was provided in city or county hospitals by medical assistants, who mainly performed tooth extraction operations [3]. If dental prosthetics was carried out, the level of theoretical knowledge and practical skills of dental prosthetics in pre-revolutionary Russia was low, since until 1881 the training of dentists and technicians was carried out only by individual apprenticeship [3-7]. There were cases where obstetricians and police doctors functioned as teachers in a dental school, with absolute absence of scientists close to the dentistry. The right to manufacture artificial teeth could be obtained from the jewelry workshop after passing the exam in the Crafts Administration, while general education and medical training were not required [3]. Thus, the quality of the dental care provided was also low. Concerning the material and instrumental equipment of dentistry organizations in orthopedic treatment, foreign methods, materials and tools were mainly used.

The emergence of insurance medicine refers to the beginning of the $20^{\text {th }}$ century. In 1912, the State Duma adopted the law “On insurance of workers in case of illness". During this period of time, mainly therapeutic and surgical dental care was provided; prosthetics was performed less frequently [4]. On October 25, 1917, with the first revolutionary shots, the medical department of the Military Revolutionary Committee of the Petrograd Council of Workers and Soldiers Deputies became the first organization of public health in the USSR [7]. Then on July 11, 1918 V.I.Lenin signed a decree on the creation of the world's first genuine people's public health authority - the People's Commissariat of Health of the RSFSR [8]. The new government was faced with the task of combating the incidence of disease among the masses on a state scale, and it was planned to create a holistic, Soviet, state medicine that would be built and developed according to a single project [9]. First Health Commissioner N. A. Semashko formulated the basic principles of Soviet medicine: generally accessible and free of charge [10]. According to these principles, reforms were carried out in the dental care, turning dentistry into a public sector by means of its nationalization, and then a resolution "On the use of private dental offices for the benefit of the working population" (September 1918) was adopted. This decree led to the fact that dentists were obliged to provide free dental care to workers by labor obligation [6]. The opening of new private offices or hospitals was prohibited by law. In cities and villages, in accordance with the density of the population, central and district factory, school and other public dental clinics and dispensaries were opened everywhere, with free provision of all types of dental care. Thus, a state system of dental care for the population of the country was created in the first years of Soviet power. In 1922, private dental care was abolished in the USSR. 
In 1923, a program of medical examination of the population was initiated on a national scale. The essence of the method of clinical examination was to take into account the need for the distribution of medical and social care. The main burden fell on the outpatient health care [11]. Also in 1923, the People's Commissariat of Health of the RSFSR issued a circular No. 114 ("Bulletin of the NKZ", 1923, No. 11, p. 4), which explained the basic legal provisions on free dental prosthetics. This document was created on the basis of the requirements of the dental subsection of the People's Commissariat of Health of the RSFSR. The list of citizens who had the right for this type of assistance included workers of production which was harmful to the oral cavity and teeth, as well as the insured, in whom the absence of teeth caused a severe chewing impairment and eating disorders. Also in this circular it was noted that the mining and smelting of lead, working with mercury, zinc, making lead paint, acid production and chemical processing of metals, electroforming, production of explosives, the work of millers, pastry chefs and bakers has a detrimental effect on the condition of the dental system [6]. A network of public dental (denture) institutions began to develop in the Soviet state. At the same time, the production of domestic dental materials, instruments and equipment was launched. In 1928, the industry of dental materials, tools and equipment completely got rid of foreign dependence [12]. Medical assistance began to be provided according to plans and estimates, which were developed together with health authorities, insurance agencies and trade unions. This type of assistance was provided free of charge to the insured and their family members. A detailed procedure for the provision and organization of medical care was approved in the Regulation "On the organization of medical care for the insured and their family members and the expenditure of funds aimed at these purposes" by the Resolution of the People's Commissariat of Health of the RSFSR and the All-Russian Central Council of Trade Unions of February 22, 1924 [13]. For the insured, the organization of treatment in outpatient clinics was provided in all specialties (in the hospitals for coming patients - polyclinics, outpatient clinics, at hospitals, etc.), the plan of providing medical care also included dental prosthetics. Medical institutions which serviced only insured citizens were financed by the medical care department of the insured. In turn, all heads of medical institutions reported to the department for the expenditure of funds allocated to them. All expenses aimed at the maintenance of medical institutions which provided medical assistance to the insured and the uninsured were beared in proportion to the number of the insured persons served by the designated institutions. In county towns and in the offices of industrial regions, medical assistance to the insured was provided according to the same organizational aspects, but in addition to the management which was directly involved in the medical care of the insured, a specially authorized person was appointed based on the manner specified in article 4. If in such towns and regions the number of insured was insignificant, then the specially authorized person might not be appointed. These decisions were considered by inter-union associations and provincial health departments. In such cases, the organization of medical care for the insured was handled by the general apparatus of the local public health authority.

During the Great Patriotic War (hereinafter - the GPW), maxillofacial orthopedics came in first place among all types of dental care. Prostheses of the face (the nose, orbit, ear, etc.) were made in people with extensive injuries both in the active army and in the rear. For the above purposes dentists-orthopedists used plastics in their practice, which had been introduced into dental prosthetics before the war. The dental subsection de- 
veloped temporary norms for orthopedic dentistry, based on the martial law in which the country was located. According to them, an extraordinary prosthetics was made for patients who were sent from the front. The indications for prosthetics were also determined: eating disorders, essential manufacture of postoperative prostheses, obturators, partial dentition defects (more than six teeth missing for one jaw) and two frontal teeth missing. According to professional indications, prosthetics was allowed even with the loss of one frontal tooth [6]. The rear workers and employees working in the defense industry had priority in providing dental care. A number of authors note that during the state of martial law in the country, the quality and availability of orthopedic dentistry declined for the entire civilian population of the country, which was due to the occupation of part of the country by the fascist invaders.

In general, during the years of the GPW, the dental industry could not fully provide population with all necessary assistance. The quality of dental care declined significantly, and accessibility for the masses was highly difficult. It was envisaged to provide only emergency dental care without a planned rehabilitation of the oral cavity and clinical examination of the population, and specialists in a number of areas were used not in their specialty (Ryazan, Smolensk, Ivanovo, Moscow, etc.). The material and technical equipment of dental institutions was given little budget; the purchase of equipment (electric drills, soldering machines, lighting devices, dental chairs, etc.) was not practically made. Since there was only emergency assistance, the procurement of materials and tools for prosthetics decreased significantly (wax, steel teeth, solder, burs, drill tips, piotsid, fluoride pastes, cement, silver amalgam, small hand and machine tools and etc.). The above defects were partly related to the occupation and blockade of the cities where most part of dental materials was located (Kharkov, Leningrad). It was expected that the quality of the instruments which were produced during that period of time remained quite low (dental probes and impression spoons, burs, dental broaches, angle tips, etc.). Some contemporaries and historians believe that the above problems could have been avoided and the quality of the assistance provided to the population at an acceptable level could be maintained if proper attention had been paid from the health authorities and the heads of dental institutions. In the first post-war decade, the policy of the Soviet state in the field of health care was aimed at restoring the industry and restructuring it from a military to a peaceful basis [14]. As a result, the main medical and sanitary measures were carried out to ensure the elimination of the serious sanitary consequences of the war, and the network of medical institutions was being restored. In all dental services there was a task of follow-up care for war invalids.

In the late 1940s, The Ministry of Health of the USSR rejected the idea of free general dental prosthetics [15]. However, there was the category of citizens with certain professions in certain industries, for which free dental prosthetics remained and planned oral rehabilitation was introduced. The categories of citizens for whom dental and facial orthopedic care was provided free of charge included:

- personal retirees;

- invalids of the GPW with injuries to the maxillofacial region;

- I and II group invalids of the GPW;

- disabled workers of I and II groups;

- old-age pensioners. 
According to V. Gonchar, this decision gave the state the opportunity to exclude rural residents from the program of preferential dental prosthetics, since until 1964 pension books hadn't been issued to collective and state farm workers [15].

In 1951, the Order of the Minister of Health of the USSR No. 977 "On marginal prices for dentures, orthodontic care for children and adolescents" was published. In this order, it was noted that dentures, which were made by students of medical dental institutes and dental schools during the course of their training, should be considered $50 \%$ below the list prices; dental technicians who made dentures in dental laboratories were allowed piecerate wages, etc. [6].

In order to expand and improve orthopedic aid to the population, the USSR Ministry of Health issued a number of instructions and letters, in particular, "On the reduction of state retail prices for dental products made of gold" (1954), "On the collection of waste containing precious metals" (1959), "On the usage and accounting of precious metals for the needs of dental prosthetics by dental institutions "(1959), etc. [6].

Funds for free (preferential) dental prosthetics were allocated by local health authorities, so its volume depended on the financial viability of the regions. In the late 1960s, only $2 \%$ of citizens of the total number of those who were to receive orthopedic constructions were provided with free prostheses in large cities [16]. According to the leading doctors of Leningrad of that period, the queues for free dental prosthetics were "especially large" because of the lack of funds for this type of care [5]. When summarizing the final results of the provision of dental orthopedic care in the postwar years in the USSR, it is possible to point out the basic principles of obtaining state dental prosthetic care, the main of which was the principle of its distribution depending on the labor input. All the working population received this assistance at their own expense. The state assumed the obligation to regulate prices, which was supposed to increase the availability of dental prosthetics for the population. Only a narrow segment of the population could enter the program of free prosthetics, those who could not earn for a living or earned very little. These principles were supposed to support equal access of the country's population to state dental prosthetics [15]. In the studies devoted to the history of the organization of dental care in the USSR, there were many attempts made by different dentists to raise the issue of general free orthopedic care for the population of the country. However, such measures were not taken by the Ministry of Health of the USSR.

In modern conditions, every citizen of the Russian Federation (hereinafter - the $\mathrm{RF}$ ) can receive medical dental care under the Territorial program of the Federal Fund for Mandatory Medical Insurance (MMI). The program does not include orthopedic dental care. On this basis, the receipt of orthopedic dental care is carried out according to the current price list for the provision of paid medical services in each specific medical organization. However, to date, preferential denture programs are carried out in different regions of Russia, which may differ depending on the region and its economic development.

\section{Conclusion}

The systemic development of dental care at the state level in Russia occurred for the first time during the years of the USSR. Medical and social dental orthopedic care has always been provided at the regional level. The procedures for obtaining this type of as- 
sistance changed depending on the time period of history and the state of the economic development of the region. General free dental prosthetics of workers was only in the prewar years of the USSR and was carried out at the expense of insurance premiums. Today, the health care system of the RF is undergoing changes and is in the process of reform. In the opinion of the authors, it is quite difficult to implement modern reforms without taking into account the historical experience of the development of domestic health care.

\section{References}

1. Kuklin G. S. Dental care organization in USSR. Moscow, Ministerstvo zdravookhraneniya SSSR Publ., 1974, pp. 44-77. (In Russian)

2. Pashkov K. A. The history of stomatology: From the origins to the $21^{\text {st }}$ century. Moscow: Pechatnyy dom "Magistral" Publ., 2018. 233 p. (In Russian)

3. Dauge P. About the main tasks of the council on the ground. Zhurnal Izvestiya Narodnogo komissariata zdravookhraneniya, 1918. (In Russian)

4. Danilov E. O. Dental service in Russia in the historical aspect. Parodontologiya, 1997, vol. 3, no. 5, pp. 74-82. (In Russian)

5. Kolegov N. I. Organization of orthopedic dental care to the population in Leningrad. Opyt organizatsii stomatologicheskoy pomoshchi v RSFSR (Moscow), 1968, pp. 13-18. (In Russian)

6. Troyanskiy G.N. The history of the development of Soviet orthopedic dentistry. Moscow, Meditsina Publ., 1975. 140 p. (In Russian)

7. Barsukov M. I. The first steps of soviet medicine. Izvestiya Sovetskoy meditsiny, 1918, pp. 6-7. (In Russian)

8. Borodulin F. R. The history of medicine. Selected lectures. Moscow, Medgiz Publ., 1961. 252 p. (In Russian)

9. Rusakov I. V. On the ratio of state and insurance medicine. Izvestiya Sovetskoy meditsiny, 1918, pp. 5-6. (In Russian)

10. Semashko N. A. The main tasks of Soviet medicine on the ground. Izvestiya Sovetskoy meditsiny, 1918, pp. 2-3. (In Russian)

11. Akulin I. M. General medical practice in the health care system of St. Petersburg. PhD thesis. St. Petersburg, 1998. 43 p. (In Russian)

12. Kolegov N. I. Organization of prosthetic care in cities. Avtoref. dis. na soiskanie uchen. stepeni kand. med. nauk. Leningrad, 1971. 16 p. (In Russian)

13. Regulations on the procedure for organizing medical care for the insured and members of their families and the expenditure of funds intended for the indicated purposes. Decree of the People's Comissariat of the Health Care dated February 22, 1924. Available by: http://www.libussr.ru/doc_ussr/ussr_1966.htm (accessed: 16.02.2020). (In Russian)

14. Byakina V.P., Davydova T. V. The legal policy of the Soviet State in the field of public health protection (1940-1950). St. Petersburg, 2017, pp. 177-178. (In Russian)

15. Gonchar V.V. Soviet dental prosthetics in the second half of the 20th century: availability and quality issues. Istoriya Meditsiny. 2016, vol. 3, no. 3, pp. 301-314. (In Russian)

16. El'bov V.L., Kuznetsov Yu. K., Blyumin I. G. Condition and ways to improve orthopedic care for the population of the Kievsky district of Moscow. Moscow, 1966, pp. 10-12. (In Russian)

Authors' information:

Evgeniya N.Antonova - Postgraduate Student; Evg-antonova@mail.ru Igor M.Akulin - MD, Dr. Sci. in Medicine; akulinim@yandex.ru TatianaV.Davydova - PhD; t-davydova@mail.ru 